\title{
Multi-Criteria Analysis in the Decision-Making Process on the Electrification of Public Transport in Cities in Poland: A Case Study Analysis
}

\author{
Marcin Wołek $^{1}$ (D), Aleksander Jagiełło ${ }^{1, *(D)}$ and Michał Wolański ${ }^{2}$ \\ 1 Faculty of Economics, University of Gdansk, 81-824 Sopot, Poland; marcin.wolek@ug.edu.pl \\ 2 Institute of Infrastructure, Transport and Mobility, Warsaw School of Economics, 02-554 Warsaw, Poland; \\ michal.wolanski@sgh.waw.pl \\ * Correspondence: aleksander.jagiello@ug.edu.pl
}

check for

updates

Citation: Wołek, M.; Jagiełło, A.; Wolański, M. Multi-Criteria Analysis in the Decision-Making Process on the Electrification of Public Transport in Cities in Poland: A Case Study Analysis. Energies 2021, 14, 6391. https://doi.org/10.3390/en14196391

Academic Editors: Grzegorz Karoń, Andrzej Szarata, Ryszard Janecki and Grzegorz Krawczyk

Received: 30 August 2021

Accepted: 29 September 2021

Published: 6 October 2021

Publisher's Note: MDPI stays neutral with regard to jurisdictional claims in published maps and institutional affiliations.

Copyright: (c) 2021 by the authors. Licensee MDPI, Basel, Switzerland. This article is an open access article distributed under the terms and conditions of the Creative Commons Attribution (CC BY) license (https:// creativecommons.org/licenses/by/ $4.0 /)$.

\begin{abstract}
Electromobility is one of the leading trends transforming public transport worldwide. Supported by international organizations, such as the European Union, and national cofounding, public transport operators and local authorities are taking strategic decisions on the direction and scope of the electrification of rolling stock. Most of the electric buses that are being put into operation replace the previously used conventional buses, and consequently, most of the electric buses are operating on existing bus lines. By applying a strategic approach to selecting bus routes for electrification, the advantages of electric vehicles can be maximized. Based on a case study of the Polish city of Gdynia, this paper explores the usefulness of the multi-criteria analysis for selecting the bus lines for electrification. Multi-criteria analysis methods help decision makers to consider and weigh diverse criteria that include, among others, economic, social, technological and environmental aspects. To fulfil the above purpose, the paper compares different methods for evaluating electromobility options at an early stage. The primary research methods include multi-criteria analysis, literature review and case study analysis. An example of using multi-criteria analysis in the decision-making process of in-motion charging trolleybuses to replace diesel buses on particular lines is discussed and concluded. It is found that the multi-criteria analysis method could be used at an early but important stage of the operational level when particular lines to be replaced are being discussed. Moreover, the case is made that the local context should always be considered, including features of the existing public transport systems, and that cost-benefit analysis should be conducted for the selected optimum scenario.
\end{abstract}

Keywords: electromobility; public transport market; multi-criteria analysis; MCA

\section{Introduction}

In 2020, electric buses accounted for $28.5 \%$ of all vehicles in Poland's completed bus supply [1]. Assessing the viability of introducing electric vehicles is always a managerial challenge. In the local public transport market, the situation is even more complex because of the different supply-side stakeholders. These are public (urban) authorities, transport authorities and operators. They should have at their disposal tools enabling them to make strategic decisions concerning the direction, scale and pace of public transport electrification. It is, therefore, important to provide support for decisions on the electrification of public transport at various stages. Furthermore, it is essential to consider the different stakeholders who operate in different regulatory environments (e.g., public authorities versus private operators), and that some decisions are also of a political nature. In the initial stages of the decision-making process, there is a need to have the tools to identify the problem and make an initial assessment of the available alternatives. The literature on the subject describes many methods and tools for assessing the legitimacy of decisions made, including decisions regarding the broadly understood urban transport. There are clear differences between the various decision support methods. This means that different methods are useful to a 
different extent in the process of electrification of public transport. The main goal of the article is, therefore, to assess the usefulness of the multi-criteria analysis (MCA) method in the first phase of electrification of public transport, i.e., at the stage of selecting the bus lines for electrification. In order to achieve the main goal of the article, the following research question was formulated:

- Is MCA a relevant method to assess the appropriateness of selecting bus lines for electrification?

The answer to this research question is particularly important in the case of cities where electrification of public transport takes place by replacing conventional buses with electric ones on existing bus lines. To carefully research the importance of the MCA in the decision-making process and to answer to the research question, a research procedure was designed to serve this purpose. In the first step, a literature review was conducted. Its main aim was to compare MCA with other methods being used in the process of public transport investment. Then, the role of the MCA in a strategic planning process was presented in relation to the example of a concrete city. Case study analysis is widely used, especially when limited cases are available or local conditions make direct comparisons more difficult. According to the pioneering work of R. K. Yin [2], the case study approach allows for the investigation of the research problem in a real context [3]. The case study methodology was found to be useful due to the complexity of the phenomena within their contexts [4]. In this specific research field, a case study methodology was selected as a leading method for research on the use of electric buses and the implementation of smart charging systems by the World Economic Forum [5]. The structure of the article was subordinated to the main goal and the main research question of the article. In Section 2, the literature review presents electromobility as a trend but also as a response to the environmental challenges facing cities. It also contains the decision-making process of the electrification of public transport and a complex overview of different tools to support it. Section 3 includes a case study description-the city of Gdynia in Poland. Section 4 includes the results of the study and describes the entire process of using MCA to evaluate the appropriateness of selecting bus lines for electrification. Finally, discussion is provided and conclusions are drawn in Section 5.

\section{Literature Review}

\subsection{Environmental Challenge for Cities in the European Union}

Nowadays, the social, political and economic role of cities is growing. The importance of environmental challenges increases [6,7] as cities compete with a widely defined quality of life and livability [8,9]. The latter entails the possibility of reducing the dependence of cities on fossil fuels acceptably and feasibly in social and economic terms [10].

The growing importance of electricity in public transport in the EU's strategic documents is a response to environmental challenges. In the European context, climate policy is of particular importance, becoming one of the most important issues determining transport development in the EU. It aims to reduce emissions of both noise and air pollutants, including greenhouse gases. The transport sector was identified as an area where significant effects could be achieved. In the last century, it was dependent on fossil fuels [11]. Concerning transport in cities, recommended activities focus on reducing the passenger car's role in travel structure for the benefit of public transport, cycling, and pedestrian traffic. Its effect was not to limit mobility but to support a more sustainable way of travelling in urban areas [12,13]. In December 2019, the European Commission presented a blueprint for reforming the European Union's climate policy-the Green Deal for Europe. It is an ambitious plan aimed at reaching climate neutrality by 2050 [14]. One of its goals is to advance the reduction in GHG emissions [15], "including the deployment of zero and low-carbon transportation fuels" [16]. It translates into a $90 \%$ reduction in emissions in the whole transport sector in the EU [14].

Today, an increasing number of cities and countries officially declare the achievement of climate neutrality within a particular time horizon. The transport sector is an essential 
source of emissions, especially at a local level [17-19]. Although public transport accounts for a much smaller proportion of emissions, its electrification is an essential first step in transforming the system, including rolling stock, charging infrastructure, and zeroemission electricity generation and storage [20]. Batteries are becoming a key component in decarbonisation and achieving the Green Deal's targets [21,22], thus increasing interest in how cobalt and rare-earth elements are being extracted [23] as well as the energy used for the battery manufacturing process [24].

\subsection{Electromobility as a Trend in the Public Transport Market in Cities}

In recent years, electromobility has been one of the leading trends in the public transport market in Poland and the European Union. However, it is not a new phenomenon. Trams and trolleybuses, which appeared at the end of the 19th century, accounted for an essential part of the public transport supply in European cities before the Second World War [25]. Due to political influence in subordinated countries of the former Soviet Union, bus transport was preferred to electric traction [26]. Moreover, shortages in liquid fuel supply were another factor supporting the electrification of bus fleets in Central European countries. Therefore, in several countries, trolleybus development peaked in the 1980s, such as in Bulgaria [27]. The most spectacular closure of trolleybus transport was noted in Moscow (Russia) in 2020, where the most extensive system was systematically diminished for years [28] and finally replaced by e-buses.

Although trolleybuses remain an essential element of the public transport supply in about 280 cities worldwide [29], it is the electric bus that sets the main directions and scope of electrification [30]. Today, the scale and pace of electrification of public transport vary from country to country. For example, decisions on the direction and scale of electrification of public transport in Poland are strongly influenced by the availability of non-refundable funds, both at a national and a European level. Decisions on electrification of public transport-as with all major city management decisions-need to be evidence-based, but also politically approved [31,32]. Both of the above factors are connected with each other, as hard evidence plays a significant and growing role in public decisions.

Electric traction was an economically and operationally effective solution in urban transport for years. It presents technological maturity but also high susceptibility to innovation [33]. It is characterised by a wide variety of applied solutions and the possibility of using virtually any means of urban transport (underground, urban rail, tram, trolleybus, electro bus, and, to a partial extent, hybrid bus). Its emissivity depends on the type of energy produced; for some cities, the share of renewable energy in transport with electric traction exceeds 90\% (including trolleybus transport in Salzburg, Austria, or Eberswalde Solingen, Germany) [34]. The advantage of electricity is its versatility: the ability to produce virtually any available energy source. It provides the foundation for the possibility of achieving the European transport policy objective of significantly reducing greenhouse gas emissions in transport [35].

\subsection{Decision-Making Process on Electrification of Public Transport}

Cities are complex systems involving different stakeholder groups [36]. The city's transport system is one of the decisive factors enabling the accessibility of other urban services. Therefore, it determines the attractiveness of a city and is an essential element in achieving the desired quality of life.

How the public transport market is organised determines the decision-making chain for fleet acquisition and propulsion choice. Typical stakeholders include the local authority, the transport authority, the transport operator, NGOs and consultancies, as well as general citizens and passengers.

Regardless of the number of stakeholders involved in the decision-making process for public transport electrification, it usually follows a similar pattern (Figure 1). 


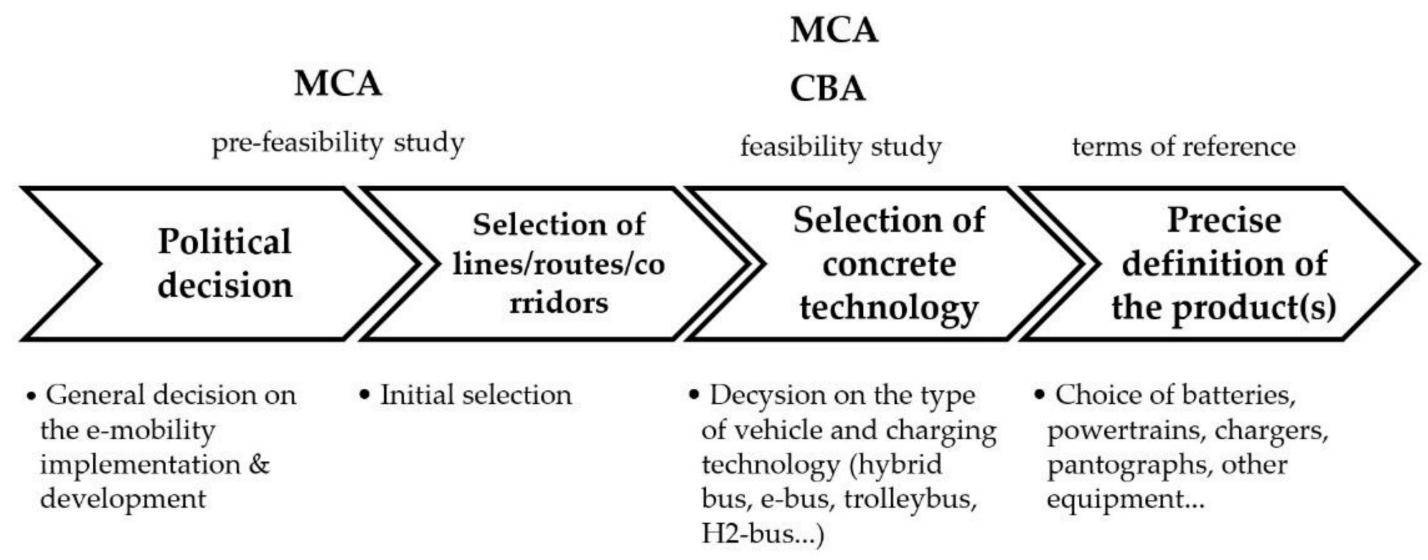

Figure 1. Decision-making process of implementing electric buses in public transport systems. Source: own elaboration.

\subsection{Tools Supporting the Decision-Making Process}

Table 1 presents the main advantages and disadvantages of the various analyses used to analyse the legitimacy and purposefulness of transport investments. Since the individual analyses answer different questions, they should not be considered as competing tools but rather as complementary tools supporting the decision-making process.

Cost-benefit analysis (CBA) is a complex method of assessing, comparing and analysing the benefits and costs of any project, such as an investment decision or a government policy. The analysis aims to establish whether any given project is feasible and effective and provide grounds for comparing different solutions to a similar socio-economic problem. [37]. The main characteristic of the CBA is that it includes all the costs and benefits of a project. Not only are financial and economic aspects included, but also social, cultural and environmental. The CBA has its roots in welfare economics. It aims to provide a framework for assessing the costs and benefits generated for different groups of stakeholders for whom the financial result is not necessarily the main optimisation criterion [38]. The CBA is a method to ensure efficient use of public financial means by summarising direct (internal) and indirect (external) costs and benefits. External costs are costs of the environment caused by activity in the environment, and they do not charge their operations directly [39].

Table 1. Summary of strengths and weaknesses of particular methods/tools regarding public transport investment.

\begin{tabular}{|c|c|c|c|c|c|}
\hline Tool/Method & $\begin{array}{c}\text { Main Advantages of } \\
\text { Analysis }\end{array}$ & $\begin{array}{c}\text { Main } \\
\text { Disadvantages } \\
\text { of Analysis }\end{array}$ & $\begin{array}{l}\text { Main Objective } \\
\text { of Analysis }\end{array}$ & $\begin{array}{l}\text { Data Required } \\
\text { for Analysis }\end{array}$ & $\begin{array}{l}\text { Result of } \\
\text { Analysis }\end{array}$ \\
\hline $\begin{array}{l}\text { Cost-benefit } \\
\text { analysis (CBA) }\end{array}$ & $\begin{array}{l}\text { Valuates all impacts } \\
\text { using a financial value } \\
\text { Includes an evaluation } \\
\text { of environmental and } \\
\text { other external effects } \\
\text { Less subjective than } \\
\text { some other analyses, } \\
\text { e.g., cost-effectiveness } \\
\text { analysis, cost-utility } \\
\text { analysis and } \\
\text { multiple-criteria analysis } \\
\text { Takes into account the } \\
\text { change in the value of } \\
\text { money over time } \\
\text { Allows for comparison } \\
\text { of very different } \\
\text { investments }\end{array}$ & $\begin{array}{l}\text { Some benefits are } \\
\text { hard to quantify } \\
\text { and measure } \\
\text { Problems with an } \\
\text { estimation if the } \\
\text { benefits apply } \\
\text { only to selected } \\
\text { groups of } \\
\text { residents } \\
\text { Different methods } \\
\text { of valuation of } \\
\text { external effects } \\
\text { may elicit } \\
\text { different } \\
\text { estimates }\end{array}$ & $\begin{array}{l}\text { Maximise the } \\
\text { utility of transport } \\
\text { investment } \\
\text { to society }\end{array}$ & Quantitative & $\begin{array}{l}\text { Net present } \\
\text { value of the } \\
\text { investment }\end{array}$ \\
\hline
\end{tabular}


Table 1. Cont.

\begin{tabular}{|c|c|c|c|c|c|}
\hline Tool/Method & $\begin{array}{c}\text { Main Advantages of } \\
\text { Analysis }\end{array}$ & $\begin{array}{c}\text { Main } \\
\text { Disadvantages } \\
\text { of Analysis }\end{array}$ & $\begin{array}{l}\text { Main Objective } \\
\text { of Analysis }\end{array}$ & $\begin{array}{l}\text { Data Required } \\
\text { for Analysis }\end{array}$ & $\begin{array}{l}\text { Result of } \\
\text { Analysis }\end{array}$ \\
\hline $\begin{array}{c}\text { Multi-criteria } \\
\text { analysis (MCA) }\end{array}$ & $\begin{array}{c}\text { It can structure an } \\
\text { assessment of a complex } \\
\text { problem } \\
\text { It makes it possible to } \\
\text { see all of the factors that } \\
\text { influence investment } \\
\text { decisions (not only } \\
\text { financial) }\end{array}$ & $\begin{array}{c}\text { The process of } \\
\text { assigning weights } \\
\text { is subjective by } \\
\text { nature } \\
\text { Takes into account } \\
\text { the preferences of } \\
\text { a relatively small } \\
\text { group of } \\
\text { decision-makers } \\
\text { and stakeholders, } \\
\text { rather than the } \\
\text { general } \\
\text { population }\end{array}$ & $\begin{array}{c}\text { Quantification } \\
\text { and scoring of } \\
\text { quantitative and } \\
\text { qualitative criteria } \\
\text { and parameters of } \\
\text { different } \\
\text { investments } \\
\text { options }\end{array}$ & $\begin{array}{l}\text { Quantitative } \\
\text { and/or } \\
\text { qualitative }\end{array}$ & $\begin{array}{l}\text { The optimal } \\
\text { variant of } \\
\text { investment in } \\
\text { terms of the } \\
\text { adopted criteria }\end{array}$ \\
\hline $\begin{array}{l}\text { Cost-effectiveness } \\
\text { analysis (CEA) }\end{array}$ & $\begin{array}{l}\text { Allows for comparison } \\
\text { of investments that } \\
\text { achieve the same } \\
\text { outcome } \\
\text { It represents the cost per } \\
\text { natural unit of the } \\
\text { outcome }\end{array}$ & $\begin{array}{l}\text { It does not allow } \\
\text { for easy } \\
\text { comparison } \\
\text { between } \\
\text { investments that } \\
\text { produce different } \\
\text { outcomes }\end{array}$ & $\begin{array}{l}\text { Minimise the cost } \\
\text { of obtaining a unit } \\
\text { effect (for } \\
\text { example, vehicle } \\
\text { kilometre or } \\
\text { passenger } \\
\text { kilometre) }\end{array}$ & Quantitative & $\begin{array}{l}\text { Cost per unit of } \\
\text { the effect of } \\
\text { investments (for } \\
\text { example, vehicle } \\
\text { kilometre or } \\
\text { passenger } \\
\text { kilometre) }\end{array}$ \\
\hline $\begin{array}{c}\text { Life-cycle } \\
\text { assessment (LCA) }\end{array}$ & $\begin{array}{l}\text { Takes into account } \\
\text { complex dependencies } \\
\text { and environmental } \\
\text { effects, including } \\
\text { scarcity } \\
\text { Allows comparison } \\
\text { between investments and } \\
\text { selection of the } \\
\text { investment that has the } \\
\text { lowest impact on the } \\
\text { environment }\end{array}$ & $\begin{array}{l}\text { Requires value } \\
\text { judgment on } \\
\text { environmental } \\
\text { priorities }\end{array}$ & $\begin{array}{l}\text { Minimise the } \\
\text { environmental } \\
\text { impact of } \\
\text { investment }\end{array}$ & Quantitative & $\begin{array}{l}\text { Assessment of } \\
\text { the } \\
\text { environmental } \\
\text { consequences of } \\
\text { each stage of the } \\
\text { vehicle life cycle }\end{array}$ \\
\hline $\begin{array}{c}\text { Life-cycle cost } \\
\text { analysis (LCCA) }\end{array}$ & $\begin{array}{l}\text { Allows comparison of } \\
\text { the life cycle costs of } \\
\text { various investment } \\
\text { variants. } \\
\text { Allows exploration of } \\
\text { trade-offs between low } \\
\text { initial costs and } \\
\text { long-term cost savings. }\end{array}$ & $\begin{array}{c}\text { Some life-cycle } \\
\text { costs may not be } \\
\text { obvious } \\
\text { Benefits are not } \\
\text { included } \\
\text { Some costs vary } \\
\text { greatly over time } \\
\text { Relies heavily on } \\
\text { the estimation }\end{array}$ & $\begin{array}{l}\text { Optimisation of } \\
\text { investment and } \\
\text { operating costs in } \\
\text { the vehicle life } \\
\text { cycle }\end{array}$ & Quantitative & $\begin{array}{l}\text { Assessment of } \\
\text { the total costs } \\
\text { throughout the } \\
\text { vehicle life cycle }\end{array}$ \\
\hline $\begin{array}{l}\text { The total cost of } \\
\text { ownership (TCO) }\end{array}$ & $\begin{array}{l}\text { Reflects the actual cost } \\
\text { of purchasing and } \\
\text { ownership rather than } \\
\text { the pure acquisition of } \\
\text { vehicles. } \\
\text { Enables the achievement } \\
\text { of a cost-saving } \\
\text { improvement of } \\
\text { investment }\end{array}$ & $\begin{array}{c}\text { Some costs of } \\
\text { ownership may } \\
\text { not be obvious } \\
\text { Benefits are not } \\
\text { included } \\
\text { Relies heavily on } \\
\text { the estimation } \\
\text { Some costs vary } \\
\text { greatly over time }\end{array}$ & $\begin{array}{c}\text { Combines } \\
\text { purchase, } \\
\text { operating, capital } \\
\text { and disposal costs } \\
\text { to identify the } \\
\text { most economical } \\
\text { choice of } \\
\text { investment }\end{array}$ & Quantitative & $\begin{array}{l}\text { Assessment of } \\
\text { the total cost of } \\
\text { vehicle } \\
\text { ownership }\end{array}$ \\
\hline
\end{tabular}


Cost-effectiveness analysis allows different methods of achieving a given outcome to be compared. It is usually not very useful while making a decision on electrifying bus lines as, in such cases, we have a given financing and aim that can optimise the output.

Life-cycle assessment quantifies the environmental impact within the lifecycle. As it does not include cost calculation, it is not sufficient, but its outcomes may be incorporated into CBA or MCA. Similarly, life-cycle cost analysis (LCCA) and total cost of ownership (TCO) include only costs, not considering outcomes, and similarly, these analyses may also be incorporated into CBA or MCA.

\section{Case Study Description: Trolleybus Transport Development in Gdynia \\ 3.1. Site Description-City of Gdynia}

Gdynia has 246,000 inhabitants. It is part of the intensively developing GdanskGdynia-Sopot metropolitan area, located on the Baltic Sea's southern coast. The population density in the city is 1823 persons $/ \mathrm{km}^{2}$. Almost half of the city area is taken up by forests [47].

A characteristic feature of the city's urban space is the central location of the seaport. This is due to the historical process of city and port development; the city was created in the 1920s and 1930s around the seaport, one of Poland's most critical investments in the interwar period.

From 1998 to 2018, there were negative changes in the travel share of public and individual transport in Gdynia. While in 1998, residents still made 60\% of their journeys by public transport, in 2018, this share dropped to $42 \%$. The main reason, as in other Polish cities, was the dynamic development of individual motorisation. In 2019, the number of passenger cars per 1000 inhabitants in Gdynia was 622, comparable to the whole country's average value (635).

Research conducted by ZKM Gdynia (Gdynia's Public Authority) showed that the share of households having at least one car increased from 56\% in 2004 to $75 \%$ in 2015 and $75 \%$ in 2018 [48].

Gdynia's public transport strategy follows the Swedish public transport market organisation with regulated competition [49] and an independent public transport authorityZKM Gdynia. There are two municipal bus operators (PKA Gdynia sp. z o.o. and PKM Gdynia sp. z o.o.), one municipal trolleybus operator (PKT Gdynia sp. z o.o.) and four other bus operators, which have a ca. $20 \%$ share in the public transport market.

\subsection{Current Status of Electric Public Transport in Gdynia}

Trolleybus transport has been operating in Gdynia since 1943. It also serves part of the neighbouring city of Sopot, which has spa status. Trolleybuses have gone through phases of development and regression [50], twice being close to liquidation. In the 1990s, the decision was taken to gradually develop the trolleybus network in quantitative and qualitative terms, which was confirmed in all the local government's strategic documents [51].

Only part of the city is being serviced by trolleybus transport. The whole northern part of Gdynia is not covered by the catenary, although an in-motion charging scheme allows trolleybuses with traction batteries to service this area.

The trolleybus transport serves the main transport corridors, providing a high density of services in the city's central districts. The annual volume of the trolleybus transport supply amounted to 5.38 Mio. vehicle-km in 2019, which constituted nearly $31 \%$ of the total share of the public transport market of Gdynia [52]. The system is operated by ca. 100 vehicles (most of them are trolleybuses made by the Solaris Bus \& Coach, Bolechowo, Poland), of which 2/3 are equipped with traction batteries (NMC and LTO). That solution enables operation in areas without access to the catenary [53], using the in-motion charging concept [54]. 


\subsection{Perspectives of Further Development of Electric Public Transport in Gdynia}

Although Gdynia has a high share of electric traction in urban transport (thanks to trolleybuses), decisions were made to purchase electric buses and trolleybuses. The local authorities' policy aligns with national and EU policies aimed at the gradual abandonment of fossil fuels [55]. Public transport is the area where satisfactory electrification effects can be achieved in a relatively short period of time. Analysis of Gdynia's strategic documents indicates a continuation of the electrification strategy while maintaining the current level of CNG powered vehicles [52,56]. In the long term, the gradual introduction of hydrogen buses is also expected (Figure 2).

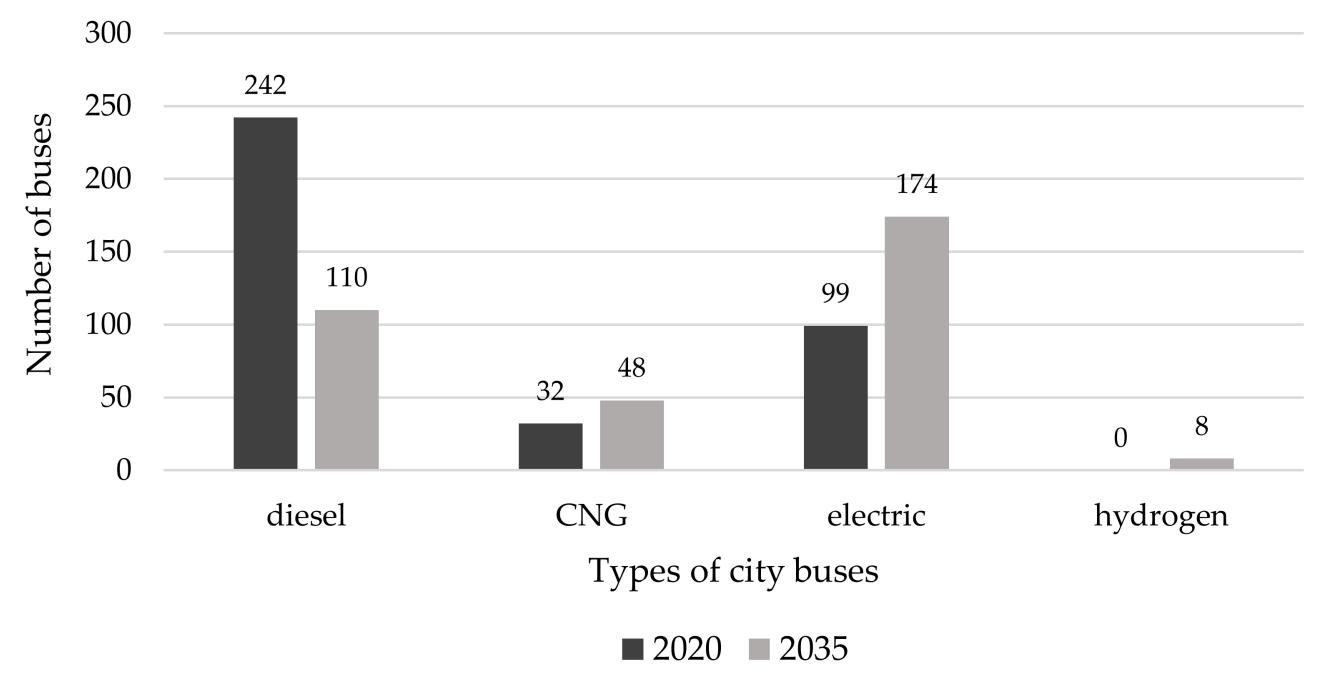

Figure 2. Transformation of the fleet of public transport in Gdynia: 2020 and 2035. Source: self-study based on [52].

The share of diesel buses is projected to decrease from the current $65 \%$ to $32 \%$ in 2035 . The trolleybus will remain a central element of the electric fleet of public transport thanks to the in-motion charging operational concept.

\section{Results-Practical Application of MCA to Support the Decision-Making Process in Gdynia}

Multi-criteria analysis (MCA) in the scientific literature is also called multiple-criteria decision-making (MCDM), multiple-criteria decision analysis (MCDA), multi-objective decision analysis (MODA), multiple-attribute decision-making (MADM) or multi-dimensional decision-making (MDDM). MCA is one of the essential tools in terms of solving various decision-making problems related to transport systems [57-60]. Therefore, multi-criteria analysis makes it possible to support investment decisions, in terms of both rolling stock and infrastructure. In selecting bus lines intended for electrification, multi-criteria analysis is one of the elements of a more extensive decision-making process. MCA can be used to make complex transport-related decisions [61].

Figure 3 shows the process of performing multi-criteria analysis. With the selection of bus lines for electrification as the goal of the decision-making process, the next step is to identify the criteria that have the most significant impact on the correctness of the decision, and thus, the legitimacy of using electric buses on a given bus line. 


\begin{tabular}{|c|c|c|}
\hline $\begin{array}{l}\text { Decision problem } \\
\text { analysis: to increase } \\
\text { scale of local zero- } \\
\text { emission public } \\
\text { transport }\end{array}$ & $\begin{array}{l}\text { Identify the } \\
\text { decision options for } \\
\text { achieving the } \\
\text { objective }\end{array}$ & $\begin{array}{l}\text { Identify the criteria } \\
\text { that compare the } \\
\text { available options } \\
\text { (Table 2) }\end{array}$ \\
\hline \multicolumn{3}{|l|}{$\vee$} \\
\hline $\begin{array}{l}\text { Assign weights for } \\
\text { each of the criteria: } \\
\text { using stakeholders' } \\
\text { opinions }\end{array}$ & $\begin{array}{l}\text { Completion of the } \\
\text { evaluation matrix } \\
\text { (Table 3) }\end{array}$ & $\begin{array}{l}\text { Overall evaluation } \\
\text { of the alternatives } \\
\text { decisions: initial set } \\
\text { of lines selected for } \\
\text { electrification }\end{array}$ \\
\hline \multicolumn{3}{|l|}{$\vee$} \\
\hline $\begin{array}{l}\text { Integration of the } \\
\text { evaluation in the } \\
\text { decision-making } \\
\text { process }\end{array}$ & $\begin{array}{l}\text { Make the final } \\
\text { decision }\end{array}$ & $\begin{array}{l}\text { Get feedback and } \\
\text { evaluate the } \\
\text { consequences of the } \\
\text { decision }\end{array}$ \\
\hline
\end{tabular}

Figure 3. The process of using multi-criteria analysis in the decision-making process on the electrification of public transport. Source: Based on [62-64]; adopted by the authors.

One of the main challenges in applying multi-criteria analysis to the selection of bus lines for electrification is the development of a set of diversified criteria. The criteria should reflect the complexity of relations between the city structure and public transportation, and they also need to be available within the budget and time given for the analysis. The list of the proposed factors is presented in Table 2. Each of the criteria was described using an indicator, thereby making Multicriteria Analysis more quantitative. It was decided not to use political or social risk criteria at this stage in order to provide hard data for further discussion, but not to replace it. In order to assess scenarios, proper engineering analysis was conducted for the Gdynia City Hall by its subsidiary PKT sp. z o. o. (the trolleybus company operating in Gdynia and in Sopot) and by ZKM Gdynia (the public transport authority). Due to time and budget limitations, LCCA/TCO and life-cycle (benefit) assessments were not included as criteria at this stage. They are required at the later stages of project preparation, integrated into CBA, in order to apply for funding, but different funding authorities require different methodologies and inputs.

Table 2. Criteria considered as the most important in the process of selecting bus lines for electrification.

\begin{tabular}{|c|c|}
\hline Criterion & Description (Method of Calculation) \\
\hline $\begin{array}{l}\text { Coverage of the bus route with } \\
\text { traction network }\end{array}$ & $\begin{array}{l}\text { Length of catenary on a given bus route/total } \\
\text { length of the route }\end{array}$ \\
\hline Servicing densely settled areas & $\begin{array}{l}\text { Length of the route in dense areas/total length } \\
\text { of the route }\end{array}$ \\
\hline Intensity of exploitation & Vehicle- $-\mathrm{km}$ 's / length of the route \\
\hline Spatial availability of the line & Number of stops/route length \\
\hline Weekly supply variation & $\begin{array}{c}\text { Supply of the given bus line on Sunday/supply } \\
\text { of the given bus line on working days }\end{array}$ \\
\hline Rolling stock utility & $\begin{array}{c}\text { Stops (hours)/ total number of vehicle-hours } \\
\text { per vehicle per working day }\end{array}$ \\
\hline
\end{tabular}

Source: own study based on opinions of stakeholders.

After developing the criteria for evaluating individual bus lines, the next step was to weigh individual criteria. Weighting is a key stage in the selection of a finite set of alternatives [65]. As evidenced by a review of multi-criteria analyses used in transport projects in 2000-2019, many different methods to assign weighting to criteria are used [40]. It was proven that the most popular methods used to solve multi-criteria decision problems 
in the field of transport in the last two decades were AHP with modifications, TOPSIS [66], DEMATEL and the weighted summation method (WSM) [67], as well as the methods encompassed in the so-called European trend, i.e., PROMETHEE and ELECTR $[40,68]$.

Due to the complexity of the bus line electrification process, many stakeholders participated in the assignment of weighting to individual criteria. It was, therefore, essential to take into account the opinions of:

- Public transport authorities;

- Public transport operators with experience in operating electric vehicles;

- Decision-makers representing local government;

- Transport specialists who focus their scientific interests around electromobility;

- Transport consulting companies;

- Non-governmental organisations.

The participation of the entities mentioned above made it possible to take into account the perspectives of many different interest groups.

A set of criteria was used to compare pre-selected diesel bus lines in Gdynia, namely $114,172,180$ and 181 (Table 3. A pre-selection process enabled the exclusion of lines that had not met basic requirements, including those that used vertical gauges or had low coverage of bus routes with trolleybus catenaries.

Table 3. Values of criteria according to particular diesel bus lines pre-selected for replacement.

\begin{tabular}{|c|c|c|c|c|c|c|c|c|c|}
\hline \multirow[b]{2}{*}{ Criterion } & \multicolumn{4}{|c|}{$\begin{array}{l}\text { Value before Taking into Account the } \\
\text { Weights of Individual Criteria }\end{array}$} & \multirow[b]{2}{*}{$\begin{array}{l}\text { Criterion } \\
\text { Weight }\end{array}$} & \multicolumn{4}{|c|}{$\begin{array}{l}\text { Value after Taking into Account the } \\
\text { Weights of Individual Criteria }\end{array}$} \\
\hline & 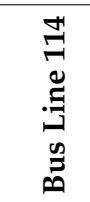 & 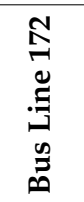 & $\begin{array}{l}\infty \\
\infty \\
0 \\
.] \\
0 \\
0 \\
0 \\
0\end{array}$ & 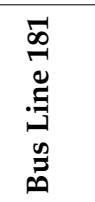 & & 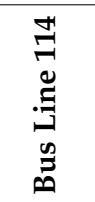 & 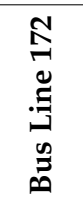 & 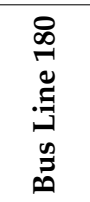 & 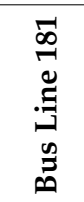 \\
\hline $\begin{array}{l}\text { Coverage of the bus route with } \\
\text { traction network }\end{array}$ & 0.36 & 0.39 & 0.66 & 0.63 & 0.20 & 0.07 & 0.08 & 0.13 & 0.12 \\
\hline Servicing densely settled areas & 0.62 & 0.78 & 0.70 & 0.75 & 0.21 & 0.13 & 0.16 & 0.15 & 0.16 \\
\hline Intensivity of exploitation & 0.51 & 0.38 & 0.37 & 1,00 & 0.17 & 0.09 & 0.07 & 0.06 & 0.17 \\
\hline Spatial availability of the line & 0.96 & 0.69 & 0.68 & 0.60 & 0.18 & 0.17 & 0.12 & 0.12 & 0.11 \\
\hline Weekly supply variation & 0.65 & 0.83 & 0.13 & 0.61 & 0.12 & 0.08 & 0.10 & 0.02 & 0.07 \\
\hline \multirow[t]{2}{*}{ Rolling stock utility } & 0.86 & 1.00 & 0.91 & 0.90 & 0.13 & 0.11 & 0.13 & 0.12 & 0.11 \\
\hline & & & & & Sum & 0.646 & 0.651 & 0.590 & 0.746 \\
\hline
\end{tabular}

Source: own study, based on [69].

\section{Discussion and Conclusions}

The decision-making process in the electrification of public transport involves many aspects and stakeholders, including those of a political nature.

The complexity of the electrification of public transport makes it difficult to obtain all of the necessary quantitative data that are useful in the decision-making process. Decision making at the initial stage does not necessarily require in-depth quantitative analyses. Instead, more qualitative issues should be taken into account in order to gain political acceptance. This approach reduces the amount of data needed at later stages and, thus, speeds up the entire decision-making process. A qualitative approach at the beginning of the decision-making process also makes it possible to take into account factors that are inherently uncountable and, at the same time, significantly affect the legitimacy of the decision. A helpful tool, in this case, is the MCA. Although it has many variations that differ in their assessment of methodology and detail, it remains a valuable tool at different stages of the decision-making process. 
In relation to the example of a medium-sized city (Gdynia), a sample methodology, using MCA, was presented. Its unique feature was the selection of criteria that covered a broad spectrum of factors (supply, demand and spatial), including the specificity of the public transport system (the trolleybus transport with in-motion charging vehicles [70]) The involvement of external experts (at the stage of selecting factors and weighing them) provided a broader overview of the issue, reducing the risk of not noticing important criteria for the entire decision-making process. The analysis results were confirmed by further measures, as a result of which several of the lines were electrified using in-motion charging trolleybuses (full electrification on line 170, part electrification on line 181). It allowed for a more precise targeting of further analyses in the field of electrification of the public transport fleet in Gdynia.

Moreover, the local context should always be taken into account, including features of the existing public transport systems. In this study, electrification of bus routes served by diesel vehicles was carried out using trolleybuses equipped with a traction battery. Therefore, one of the key criteria was the degree of route coverage by the trolleybus network. This was one of the 'local' factors, which was specific only to trolleybus cities. The application of the MCA method made it possible to take such a specific criterion into account.

In terms of deciding on the electrification of public transport, MCA is a recommended method to select the optimum investment scenario. It allows for the inclusion of various differentiating impacts that cannot be easily valuated, which constitutes its advantage over CBA. In particular, it may include political risks, which are an important determinant of all major public decisions. However, in the case of public transport electrification, which is not a major infrastructure project, as it uses mostly existing infrastructure, we decided not to include those factors.

Nevertheless, MCA does not provide objective information on value for money. In particular, it does not provide information if the optimum scenario of electrifying a line is more beneficial than the business-as-usual scenario, which usually means keeping a line diesel-powered. Therefore, CBA for the optimum investment scenario compared to the reference one is also recommended as a supplementary method. CBA also makes it possible to include lifetime costs (TCO/LCCA) and benefits (LCA) quantitatively in the investment assessment; however, this can also potentially be achieved within MCA, depending on the resources available. A method for its application was presented by Wołek et al. [50].

Further analyses are still needed on how best to assess the validity of introducing electric buses into service. According to the authors, these analyses should concern, inter alia, the practical possibilities of using the popular methods of analysis presented above, the usefulness of which has been proven during the evaluation of other transport projects. Further analyses will make it possible to carry out the progressive process of electrification of public transport in the most economically effective manner in Poland, the EU and around the world.

Author Contributions: Conceptualisation, M.W. (Michał Wolański), M.W. (Marcin Wołek) and A.J.; methodology, M.W. (Michał Wolański) and A.J.; formal analysis, M.W. (Marcin Wołek) and A.J.; investigation, M.W. (Marcin Wołek); resources, M.W. (Michał Wolański); data curation, M.W. (Marcin Wołek) and A.J; writing-original draft preparation, M.W. (Marcin Wołek) and A.J.; visualisation, M.W. (Marcin Wołek); supervision, M.W. (Michał Wolański); project administration, A.J. All authors have read and agreed to the published version of the manuscript.

Funding: The considerations presented in the article are based on the knowledge acquired during the following research projects: TROLLEY 2.0-Trolleybus Systems for Smart Cities, ERA-NET Cofund Electric Mobility Europe (EMEurope), cofunded by the European Commission as part of the ERA-NET Cofund scheme under the Horizon 2020 Programme within the EU funding programme for research and innovation under grant agreement no. 723977; and ELIPTIC-Electrification of Public Transport in Cities, funded by the European Union's Horizon 2020 research and innovation programme under grant agreement no 636012. 
Institutional Review Board Statement: Not applicable.

Informed Consent Statement: Not applicable.

Data Availability Statement: Not applicable.

Acknowledgments: We would like to thank all the specialists who participated in the process of assigning weight to individual criteria considered as the most important in the process of selecting bus lines for electrification.

Conflicts of Interest: The authors declare no conflict of interest.

\section{References}

1. TransInfo Polski Rynek Autobusów Elektrycznych w 2020 r. Available online: https://transinfo.pl/infobus/polski-rynekautobusow-elektrycznych-w-2020-r/?fbclid=IwAR0wlAVdhB0qUe0REDapK_UOdF0AZgE2oKbRuSOmM9xNTvZbIMKutjb2tA (accessed on 1 July 2021).

2. Yin, R.K. Case Study Research: Design and Methods, 5th ed.; SAGE Publications: Thousand Oaks, CA, USA, 2013.

3. Bjørner, T. The advantages of and barriers to being smart in a smart city: The perceptions of project managers within a smart city cluster project in Greater Copenhagen. Cities 2021, 114, 103187. [CrossRef]

4. Canitez, F.; Çelebi, D.; Beyazit, E. Establishing a metropolitan transport authority in Istanbul: A new institutional economics framework for institutional change in urban transport. Case Stud. Transp. Policy 2019, 7, 562-573. [CrossRef]

5. World Economic Forum. World Economic Forum. World Economic Forum White Paper. In Digital Transformation of Industries: In Collaboration with Accenture; Digital Enterprise; World Economic Forum: Cologny, Switzerland, 2016.

6. Urbanek, A. Pomiar zrównoważonej mobilności miejskiej: Przegląd badań. Stud. Pr. Kol. Zarzadzania Finans 2019, 171, 61-80. [CrossRef]

7. Mirzahossein, H.; Mohghaddam, S.A.A. Increasing Citizen's Livability In The Future City: Responsive City, A Remarkable Solution. Theor. Empir. Res. Urban Manag. 2021, 16, $23-41$.

8. Kaklauskas, A.; Zavadskas, E.K.; Radzeviciene, A.; Ubarte, I.; Podviezko, A.; Podvezko, V.; Kuzminske, A.; Banaitis, A.; Binkyte, A.; Bucinskas, V. Quality of city life multiple criteria analysis. Cities 2018, 72, 82-93. [CrossRef]

9. Mittal, S.; Chadchan, J.; Mishra, S.K. Review of Concepts, Tools and Indices for the Assessment of Urban Quality of Life. Soc. Indic. Res. 2020, 149, 187-214. [CrossRef]

10. Newman, P.; Beatley, T.; Boyer, H. Resilient Cities. Responding to Peak Oil and Climate Change; Island Press: Washington, DC, USA, 2009; ISBN 978-1597264990.

11. Wimbadi, R.W.; Djalante, R.; Mori, A. Urban experiments with public transport for low carbon mobility transitions in cities: A systematic literature review (1990-2020). Sustain. Cities Soc. 2021, 72, 103023. [CrossRef]

12. Komisja Europejska. Biata Księga. Plan Utworzenia Jednolitego Europejskiego Obszaru Transportu—Dą̇enie do Osiagnięcia Konkurencyjnego i Zasobooszczędnego Systemu Transportu; Komisja Europejska: Bruksela, Belgium, 2011.

13. Jagiełło, A. Elektromobilność w Kształtowaniu Rozwoju Drogowego Transportu Miejskiego w Polsce; Wydawnictwa Uniwersytetu Gdańskiego: Gdańsk, Poland, 2021.

14. European Commission. The European Green Deal. Communication from the Commission to the European Parliament, the European Council, the Council, the European Economic and Social Committee and the Committee of the Regions; European Union: Brussels, Belgium, 2019.

15. Becchetti, L.; Piscitelli, P.; Distante, A.; Miani, A.; Uricchio, A.F. European Green Deal as social vaccine to overcome COVID-19 health \& economic crisis. Lancet Reg. Heal. Eur. 2021, 2, 100032.

16. Chiaramonti, D.; Talluri, G.; Scarlat, N.; Prussi, M. The challenge of forecasting the role of biofuel in EU transport decarbonisation at 2050: A meta-analysis review of published scenarios. Renew. Sustain. Energy Rev. 2021, 139, 110715. [CrossRef]

17. Sówka, I.; Bezyk, Y. Greenhouse gas emission accounting at urban level: A case study of the city of Wroclaw (Poland). Atmos. Pollut. Res. 2018, 9, 289-298. [CrossRef]

18. Ajanovic, A.; Haas, R. Dissemination of electric vehicles in urban areas: Major factors for success. Energy 2016, 115, 1451-1458. [CrossRef]

19. Kalbar, P.P.; Birkved, M.; Hauschild, M.; Kabins, S.; Nygaard, S.E. Environmental impact of urban consumption patterns: Drivers and focus points. Resour. Conserv. Recycl. 2018, 137, 260-269. [CrossRef]

20. Bartlomiejczyk, M.; Jarzebowicz, L. Utility analysis and rating of energy storages in trolleybus power supply system. In Proceedings of the 2020 Zooming Innovation in Consumer Technologies Conference (ZINC), Novi Sad, Serbia, 26-27 May 2020; pp. 237-241.

21. Mancini, L.; Eslava, N.A.; Traverso, M.; Mathieux, F. Assessing impacts of responsible sourcing initiatives for cobalt: Insights from a case study. Resour. Policy 2021, 71, 102015. [CrossRef]

22. da Silva Lima, L.; Quartier, M.; Buchmayr, A.; Sanjuan-Delmás, D.; Laget, H.; Corbisier, D.; Mertens, J.; Dewulf, J. Life cycle assessment of lithium-ion batteries and vanadium redox flow batteries-based renewable energy storage systems. Sustain. Energy Technol. Assess. 2021, 46, 101286.

23. Silvestri, L.; Forcina, A.; Silvestri, C.; Traverso, M. Circularity potential of rare earths for sustainable mobility: Recent developments, challenges and future prospects. J. Clean. Prod. 2021, 292. [CrossRef] 
24. Jelti, F.; Allouhi, A.; Al-Ghamdi, S.G.; Saadani, R.; Jamil, A.; Rahmoune, M. Environmental life cycle assessment of alternative fuels for city buses: A case study in Oujda city, Morocco. Int. J. Hydrog. Energy 2021, 6, 25308-25319. [CrossRef]

25. The Trolleybus as an Urban Means of Transport in the Light of the Trolley Project; Wolek, M.; Wyszomirski, O. (Eds.) University of Gdansk Press: Sopot, Poland, 2013; ISBN 9788378651741.

26. Fitzová, H.; Matulová, M. Comparison of urban public transport systems in the Czech Republic and Slovakia: Factors underpinning efficiency. Res. Transp. Econ. 2020, 81, 100824. [CrossRef]

27. Petkov, D. The uneven development path of Bulgarian trolleybus transport-Leading back to the future? Case Stud. Transp. Policy 2020, 8, 1383-1392. [CrossRef]

28. Ryzhkov, A.; Sarzhan, Y. Market initiative and central planning: A study of the Moscow bus network. Res. Transp. Econ. 2020, 83, 100919. [CrossRef]

29. Bartłomiejczyk, M.; Połom, M. Sustainable use of the catenary by trolleybuses with auxiliary power sources on the example of gdynia. Infrastructures 2021, 6, 61. [CrossRef]

30. He, Y.; Liu, Z.; Song, Z. Optimal charging scheduling and management for a fast-charging battery electric bus system. Transp. Res. Part E Logist. Transp. Rev. 2020, 142, 1-24. [CrossRef]

31. Cairney, P. The Politics of Evidence-Based Policy Making; Palgrave Macmillan: Stirling, UK, 2016.

32. Sutcliffe, S.; Court, J. Evidence-Based Policymaking: What is it? How does it work? What Relevance for Developing Countries? 2005. Available online: https:/ /cdn.odi.org/media/documents/3683.pdf (accessed on 1 June 2021).

33. Rogge, M.; van der Hurk, E.; Larsen, A. Dirk Uwe Sauer Electric bus fleet size and mix problem with optimization of charging infrastructure. Appl. Energy 2018, 211, 282-295. [CrossRef]

34. Trolley:2.0 - Trolley Systems for Smart Cities. Available online: https://www.trolleymotion.eu/trolley2-0/ (accessed on 12 March 2021).

35. Bartłomiejczyk, M.; Kołacz, R. The reduction of auxiliaries power demand: The challenge for electromobility in public transportation. J. Clean. Prod. 2020, 252, 119776. [CrossRef]

36. Zhao, P.; Chapman, R.; Randal, E.; Howden-Chapman, P. Understanding resilient urban futures: A systemic modelling approach. Sustainability 2013, 5, 3202-3223. [CrossRef]

37. Quah, E.; Mishan, E.J.; Quah, E. Cost-Benefit Analysis, 5th ed.; Routledge: London, UK, 2007; ISBN 9780415349918.

38. ITF. Quantifying the Socio-Economic Benefits of Transport; OECD Publishing: Paris, France, 2017.

39. Jugović, A.; Mikuličić, J.Ž.; Maglić, L. Impact of external costs on the implementation of Motorways of the Sea system. Pomorstvo 2014, 28, 17-21.

40. Broniewicz, E.; Ogrodnik, K. Multi-criteria analysis of transport infrastructure projects. Transp. Res. Part D Transp. Environ. 2020, 83, 102351. [CrossRef]

41. Boardman, A.E.; Greenberg, D.H.; Vining, A.R.; Weimer, D.L. Cost-Benefit Analysis: Concepts and Practice; Cambridge University Press: Cambridge, UK, 2018.

42. Fernandes, L.; Ridgley, M.A.; Van't Hof, T. Multiple criteria analysis integrates economic, ecological and social objectives for coral reef managers. Coral Reefs 1999, 18, 393-402. [CrossRef]

43. Dodgson, J.S.; Spackman, M.; Pearman, A.; Phillips, L.D. Multi-Criteria Analysis: A Manual; Department for Communities and Local Government, Eland House, Bressenden Plac: London, UK, 2009; Volume 11, ISBN 9781409810230.

44. Wood, M. The Pros and Cons of Using Pros and Cons for Multi-Criteria Evaluation and Decision Making. SSRN Electron. J. 2011. Available online: https:/ / ssrn.com/abstract=1545189 (accessed on 1 June 2021).

45. Filimonau, V. Life Cycle Assessment (LCA) and Life Cycle Analysis in Tourism; Springer: Cham, Switzerland, 2016; ISBN 9783319262222.

46. Palmer, K.; Tate, J.E.; Wadud, Z.; Nellthorp, J. Total cost of ownership and market share for hybrid and electric vehicles in the UK, US and Japan. Appl. Energy 2018, 209, 108-119. [CrossRef]

47. City of Gdynia. Studium Uwarunkowań i Kierunków Zagospodarowania Przestrzennego Gdyni [Spatial Masterplan of the City of Gdynia]; City of Gdynia: Gdynia, Poland, 2019.

48. ZKM Gdynia. Preferencje i Zachowania Komunikacyjne Mieszkańców Gdyni. Raport z Badań Marketingowych 2018. [Preferences and Transport Behavior of Citizens of Gdynia. Marketing Research Report 2018]; ZKM Gdynia: Gdynia, Poland, 2019.

49. Decker, B.; Hećimović, H.; Wołek, M. Sustainable Urban Mobility Planning in Central Eastern Europe: Case Examples from Poland and Croatia. Procedia Soc. Behav. Sci. 2012, 48, 2748-2757. [CrossRef]

50. Wołek, M.; Wolański, M.; Bartłomiejczyk, M.; Wyszomirski, O.; Grzelec, K.; Hebel, K. Ensuring sustainable development of urban public transport: A case study of the trolleybus system in Gdynia and Sopot (Poland). J. Clean. Prod. 2021, 279, 123807. [CrossRef]

51. Wołek, M.; Hebel, K. Strategic Planning of the Development of Trolleybus Transportation within the Cities of Poland. In Smart and Green Solutions for Transport Systems. 16th Scientific and Technical Conference "Transport Systems. Theory and Practice 2019" Selected Papers; Sierpinski, G., Ed.; Springer Nature: Cham, Switzerland, 2020; ISBN 978-3-030-35543-2.

52. Gdynia City Council. Strategia Rozwoju Elektromobilności dla Gminy Miasta Gdynia do 2035 roku [Strategy of Electromobility for the Commune of Gdynia City to 2035]; Gdynia City Council: Gdynia, Poland, 2020.

53. Wołek, M.; Szmelter-Jarosz, A.; Koniak, M.; Golejewska, A. Transformation of trolleybus transport in Poland. Does in-motion charging (technology) matter? Sustainability 2020, 12, 9744. [CrossRef] 
54. Bartłomiejczyk, M. Praktyczna aplikacja In Motion Charging w Gdyni: Trolejbusy w obsłudze linii autobusowych. Autobusy Tech. Eksploat. Syst. Transp. 2016, 7-8, 58-64.

55. Połom, M.; Wiśniewski, P. Implementing electromobility in public transport in poland in 1990-2020. A review of experiences and evaluation of the current development directions. Sustainability 2021, 13, 4009. [CrossRef]

56. Gdynia City Council Strategia Rozwoju Gdyni [Strategy of Development of the City of Gdynia] 2017. Available online: http: / / 2030.gdynia.pl/cms/fck/uploaded/strategia\%20rozwoju\%20miasta\%20gdyni\%202030_folder.pdf (accessed on 15 June 2021).

57. Deluka-Tibljaš, A.; Karleuša, B.; Dragičevič, N. Review of muiticriteria-analysis methods application in decision making about transport infrastructure. Gradjevinar 2013, 65, 619-631.

58. Iniestra, J.G.; Gutiérrez, J.G. Multicriteria decisions on interdependent infrastructure transportation projects using an evolutionarybased framework. Appl. Soft Comput. J. 2009, 9, 512-526. [CrossRef]

59. Dahlgren, S.; Ammenberg, J. Sustainability assessment of public transport, part—applying a multi-criteria assessment method to compare different bus technologies. Sustainability 2021, 13, 1273. [CrossRef]

60. Tzeng, G.H.; Lin, C.W.; Opricovic, S. Multi-criteria analysis of alternative-fuel buses for public transportation. Energy Policy 2005, 33, 1373-1383. [CrossRef]

61. Hasan, M.A.; Chapman, R.; Frame, D.J. Acceptability of transport emissions reduction policies: A multi-criteria analysis. Renew. Sustain. Energy Rev. 2020, 133, 110298. [CrossRef]

62. Spackman, M.; Pearman, A.D.; Phillips, L.D. Multi-Criteria Analysis: A Manual; 2009; ISBN 9781409810230.

63. De Brucker, K.; Verbeke, A.; Macharis, C. The Applicability of Multicriteria-Analysis To the Evaluation of Intelligent Transport Systems (Its). Res. Transp. Econ. 2004, 8, 151-179. [CrossRef]

64. Hamurcu, M.; Eren, T. Electric bus selection with multicriteria decision analysis for green transportation. Sustainability 2020, 12, 2777. [CrossRef]

65. Yeh, C.H.; Willis, J.R.; Deng, H.; Pan, H. Task oriented weighting in multi-criteria analysis. Eur. J. Oper. Res. 1999, 119, 130-146. [CrossRef]

66. Feizi, A.; Joo, S.; Kwigizile, V.; Oh, J.S. A pervasive framework toward sustainability and smart-growth: Assessing multifaceted transportation performance measures for smart cities. J. Transp. Heal. 2020, 19, 100956. [CrossRef]

67. Kügemann, M.; Polatidis, H. Multi-criteria decision analysis of road transportation fuels and vehicles: A systematic review and classification of the literature. Energies 2019, 13, 157. [CrossRef]

68. Manzolli, J.A.; Trovão, J.P.; Henggeler Antunes, C. Scenario-Based Multi-criteria decision analysis for rapid transit systems implementation in an urban context. Transportation 2021, 7, 100101.

69. Wołek, M.; Wolanski, M.; Jagiełło, A.; Suchanek, M.; Szmelter, A. 3.4. Conventional Full Evaluation. The Test Results; Elaborated within the ELIPTIC prject (H2020 Programme contract nr636012). Department for Communities and Local Government: London, UK, 2018. Available online: https:/ / www.eliptic-project.eu/sites/default/files/ELIPTIC\%20D3.4\%20Conventional\%20Full\%20 Evaluation\%2C\%20the\%20test\%20results.pdf (accessed on 11 May 2021).

70. Bartłomiejczyk, M.; Połom, M. Possibilities for developing electromobility by using autonomously powered trolleybuses based on the example of Gdynia. Energies 2021, 14, 2971. [CrossRef] 